\title{
Thematic Practicum Handbook Theme 2: Student Interests and Critical Thinking Skills for Fourth Grade Elementary School Students
}

\author{
Arsil1 $^{*}$, Silvina Noviyanti², Dwi Agus Kurniawan ${ }^{3}$, Muhammad Dewa Zulkhi ${ }^{4}$, Juwita \\ Saputri ${ }^{5}$, Ninda Silvia ${ }^{6}$, Nurul Delima Kiska ${ }^{7}$, Latipia Damayanti ${ }^{8}$, Ubaidillah ${ }^{9}$ \\ 1,2,4,5,6,7,8,9 Pendidikan Anak Usia Dini dan Dasar, Universitas Jambi, Jambi, Indonesia \\ ${ }^{3}$ Pendidikan fisika, Universitas Jambi, Jambi, Indonesia
}

\section{ART I C L E I N F O}

Article history:

Received August 08, 2021

Revised August 11, 2021

Accepted September 22, 2021

Available online November 25, 2021

\section{Kata Kunci}

Buku, Berpikir Kritis, Minat Siswa

Keywords:

Book, Critical Thinking, Student Interests

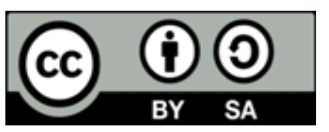

This is an open access article under the CC BY-SA license.

Copyright (c) 2021 by Author. Published by Universitas Pendidikan Ganesha.

\begin{abstract}
ABSTRAK
Pembelajaran tematik dengan muatan utama sains bukanlah pembelajaran yang hanya menghafalkan konsep-konsep saja. Akan tetapi, perlu sebuah pembelajaran dimana siswa mengalami dan mencari sendiri. Pembelajaran yang dimaksud merupakan pembelajaran berbasis praktikum. Tujuan dilakukan penelitian ini adalah menelaah pengaruh dari pengembangan sebuah buku panduan pratikum terhadap minat dan kemampuan berpikir kritis siswa. Metode penelitian yang digunakan yaitu jenis penelitian dan pengembangan atau R\&D dengan model prosedural 4D. Sampel pada penelitian ini adalah peserta didik kelas IV berjumlah 137 siswa, dengan teknik sampling yaitu sampling purposive. Peneliti menggunakan angket sebagai instrumen pengumpulan data. Angket yang digunakan terdiri dari angket minat siswa dan berpikir kritis. Analisis data menggunakan statistik desktriptif dan uji regresi. Statistik deskriptif digunakan untuk menganalisis data dengan cara mendeskripsikan atau menggambarkan data yang telah terkumpul. Hasil penelitian ini adalah minat belajar siswa dan kemampuan berpikir kritis siswa berkategori baik. Hasil uji regresi mengungkapkan bahwasanya pengimplementasian buku pedoman pratikum tematik tema 2 berpengaruh pada minat dan kemampuan berpikir kritis siswa. Implikasi penelitian \& pengembangan buku pedoman pratikum tematik tema 2 dalam pembelajaran kelas IV yaitu sebagai bahan petunjuk pratikum. Maka dari itu, buku panduan praktikum sangat perlu digunakan dalam proses pembelajaran oleh guru maupun siswa untuk meningkatkan dan mengembangkan minat serta kemampuan berpikir kritis siswa.
\end{abstract}

A B S T R A C T

\begin{abstract}
Thematic learning with the main content of science is not learning that only memorizes concepts. However, there needs to be learning where students experience and find out for themselves. The learning in question is practicum-based. This research aims to examine the effect of developing a practical guidebook on students' interests and critical thinking skills. The research method used is the type of research and development or R\&D with a 4D procedural model. The sample in this study was 137 students in class IV, with a sampling technique of purposive sampling. Researchers used a questionnaire as a data collection instrument. The questionnaire used consisted of a student interest questionnaire and critical thinking. Data analysis used descriptive statistics and regression tests. Descriptive statistics are used to analyze data by describing or describing the data that has been collected. The results of this study are that students' interest in learning and students' critical thinking skills are categorized as good. The results of the regression test revealed that the implementation of the thematic practicum guidebook theme 2 affected students' interest and critical thinking skills. The implications of the research \& development of the thematic practicum guidebook theme 2 in class IV learning are practical guide material. Therefore, it is essential to use a practicum manual in the learning process by both teachers and students to increase and develop students' interests and critical thinking skills.
\end{abstract}




\section{INTRODUCTION}

Thematic learning is a learning plan that leaves learning that has independent subjects (Ardiani et al., 2013; Ma'ratusholihah et al., 2019; Riani et al., 2019). Specific topics are described in one aspect of the lesson with a unifying theme, namely the theme. The implementation of thematic learning is more in line with children's psychology's physical and mental development (Krissandi, 2018; Sunarti et al., 2016; Suyono et al., 2017). Thematic learning combines cognitive, psychomotor and the main thing is effective. Thematic learning provides students hands-on experience and comprehensive learning (Muskania et al., 2019; Riwanti \& Hidayati, 2019). Students will work hard to gain experience and train students to know precisely what they are learning (Candra et al., 2018; Setiawan, 2020). So that learning is helpful and focused on the needs of children and their development. Thematic learning will be maximized if in the learning process using a teaching material. In thematic learning, the use of teaching materials can assist in the understanding of students. Teaching materials are used to assist teachers in the learning process (Samri et al., 2020; Yuniarti \& Radia, 2020). The teaching materials used will determine each defined basic competency (A. Nugroho et al., 2021; Sugiyanto et al., 2019). On the other hand, if the teaching materials do not meet the criteria, various learning problems will arise (Rosala \& Budiman, 2020; Syafrijal \& Desyandri, 2019). However, the teaching materials used should help the learning process, and the complete achievement of the basic skills developed. However, on the other hand, if the teaching materials used do not meet the criteria and basic skill requirements, various learning problems will arise (Misbah et al., 2018; Mulyati et al., 2021).Especially in the thematic learning for class IV theme 2, "Always Save Energy," the primary material discussed is energy sources, and there are other materials that are by existing competencies. In this theme, students need to know the reasons and how to save energy can be done.

Practicum-based learning is a learning presentation where students prove and experience what they learn for themselves by conducting experiments (Hartini et al., 2017; Muzijah et al., 2020; Syafrijal \& Desyandri, 2019). In the implementation of the practicum, an essential practicum device is needed, namely practicum guidelines. The practicum guide contains practical instructions as guidelines for the preparation, implementation, and reporting of practicum so that the practicum implementation is more focused, planned, and systematic (Gavrilenko, 2018; Hadiyanti et al., 2021; Silva et al., 2018). In general, the term practicum is closer to science learning. In essence, science learning teaches about scientific products, processes, and attitudes. These three things cannot be achieved only by theory and memorization (Alnajdi, 2018; Sakliressy et al., 2021; Suarsana et al., 2018). Science learning must involve students in practical activities. Science learning in elementary schools memorizes a collection of concepts, but learning must be carried out with investigations or simple practicums (Bettencourt et al., 2011; Kurniawan et al., 2019). Therefore, practicum-based learning is a student-centered activity. Based on the observations that have been made, the researchers found that there were no specific practical guidelines in learning. The practical guidelines used are student books and worksheets, which contain a combination of teaching materials and practicum activities. The author analyzes student books. There are practicum activities that are not by the competencies of elementary school students. Some practicum guidelines do not include the title and purpose of the practicum. There are also practical guidelines that do not explain the steps of practical work, and there are practical guidelines that are not accompanied by an observation sheet. The author also analyzes the LKS. It is known that there is no title and purpose of the practicum that will be carried out. The guidelines are directly on the tools, materials, and practical work steps, the paper used is not see-through, and the color used is black and white, so it does not attract students' attention. In addition to student books and worksheets, there are practical guidelines delivered by the teacher.

Practical guidelines are not all by the abilities or competencies of elementary school students. Some practical instructions are more suitable for secondary schools, considering the characteristics and abilities of elementary school students who are different from high school students. In addition, the available practicum guidelines have not been designed to help students develop basic science process skills. Science process skills are skills obtained from basic skills (Asrial, Syahrial, Maison, Kurniawan, \& Perdana, 2020; Gürsoy, 2021; Rubini et al., 2018). The basic process skills of science are only the skills to observe, communicate, and conclude. Basic science process skills are essential because they instill scientific traits and train them to carry out scientific investigations, becoming vehicles for developing concepts, attitudes, and values (Faisal \& Martin, 2019; Lee \& Kim, 2018; Asep Samsudin et al., 2019). Meanwhile, students must understand the concept, master the process, and have a scientific attitude such as curiosity and critical thinking. Critical thinking is a thinking ability that is part of higher-order thinking (P. B. Nugroho et al., 2018; Sapeni \& Said, 2020; Saprudin et al., 2019). Critical thinking skills can be defined as the ability to think logically and effectively to solve problems. Critical thinking is included in students' skills in the applicable curriculum standards, namely the 2013 curriculum. Students who think critically will put their existing knowledge into practice and change their previous knowledge by evaluating their thinking (McCormick et al., 2015; Purnami et al., 2021; Seruni et al., 2020). Students' critical thinking needs to be sharpened to 
reflect critically and formulate solutions to everyday problems (Mutakinati \& Anwari, 2018; Yaldiz \& Bailey, 2019). Critical thinking can also reflect and become rational thinking in depth. Students with low critical thinking skills will have difficulty improving them because they cannot assess weaknesses in their thinking processes (Arsy et al., 2020; Turan \& Koç, 2018). Factors that affect critical thinking skills include psychological factors such as intellectual development, anxiety, and interest.

In the learning process, interest is the initial movement for students in learning that can achieve the desired goals (Fauziah et al., 2017; Tanti et al., 2020). Interest in learning greatly influences learning outcomes because, with interest, students will evaluate learning (Tanti et al., 2019; Wahyuningsih et al., 2021). Interest in learning is a motivating factor for students in learning based on students' desire to learn (Arico et al., 2018; Hwang et al., 2012). Interest in learning is very influential on learning because if the learning material being studied is not in students' interests, students will not learn as well as possible (Asrial, Syahrial, Maison, Kurniawan, \& Piyana, 2020; Wang et al., 2015). Learning in elementary schools with science content has not achieved maximum results and is still far from what is expected. The low quality of science-laden learning is due to the lack of student interest in the learning process (Awe \& Benge, 2017; Rubini et al., 2018). In terms of learning, students will study hard or not depending on the attitudes and interests of each student.

The gap between this research and previous research is that critical thinking requires aspects that play a role in supporting learning success, such as critical thinking media (Fitriani et al., 2021). So that it can analyze the needs of teachers and students in instilling these abilities. Critical thinking is a source of development for students, carried out by implementing a curriculum that is not rigid (Andayani, 2017; Nugraha et al., 2017). Meanwhile, student interest is enhanced by portfolio assessment and learning models in research (Wright et al., 2018; Draijer et al., 2020). Furthermore, the development of a picture book proved to help students in learning. Therefore, the researchers aimed to develop a thematic practicum book, Theme 2, "Always Save Energy," in this study. So that later the books that have been developed can be used by elementary school students, especially fourth-grade students. Theme 2 thematic practicum books that have been completed and validated will be implemented in the learning process. Implementing this Theme 2 thematic practicum book in learning aims to increase students' interest in learning and critical thinking skills.

\section{METHOD}

This research is a type of research and development or R\&D. The product developed is a Theme 2 thematic practicum manual for grade IV elementary school. This research and development use a 4-D development model. The 4-D development model consists of 4 stages of development. The stages of the 4D model are defined, designed, developed, and disseminated (Nurmanita et al., 2019). The development procedure refers to the 4-D model. The following is the flow of this research using the 4-D model (Achmad Samsudin et al., 2021).

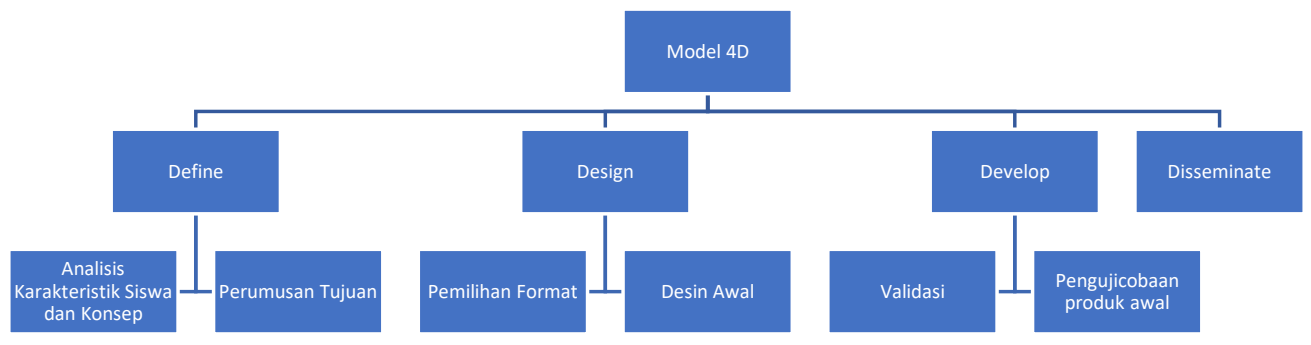

Figure 1. 4D Model Flow

In the $4 \mathrm{D}$ model, the first stage is the define stage. The definition stage aims to determine the learning conditions. At this stage, the authors conducted several analyzes, namely the analysis of student characteristics, concept analysis, and formulation of learning objectives. The second stage is the design stage. The design phase aims to design the product to be developed. At this stage, it is still a sketch of the product to be made. Product design in this development is choosing the format or book components to be used and making the initial design. Next, there is the development stage. At the development stage, the product is generated from the initial design. The initial design made in the previous stage will be 
implemented at this stage. Then the products that have been made are tested for validity, and small group trials and large group trials are carried out. The last stage is the disseminate stage. The dissemination stage is a book developed in a practical manual based on basic science process skills used in other classes, other teachers, or other schools. The population in this study were all students of SD Negeri 45/I Sridadi. This study uses a sampling technique that is purposive sampling. The criteria considered by the researcher is that learning with science content has not been applied to practicum-based learning. As well as the absence of a practicum guidebook for students and students' critical thinking skills, teachers have not trained and developed it. The sample is the part taken from the population, which can represent the population. So that the sample in this study was all fourth-grade students of SD Negeri 45/I Sridadi, totaling 137 students.

The data types taken in this study are grouped into two parts, namely qualitative and quantitative data. Qualitative data were obtained from the stage of criticism, suggestions, and responses from the material validator, media validator, evaluation validator, and teacher. Validation of the validator needs to be done because the development of suitable teaching materials meets three criteria, namely valid, practical, and efficient. Responses from each validator were obtained using an assessment instrument. The assessment instrument contains criteria that describe the validity of the product being developed. Moreover, there is a column for writing criticism, suggestions, and responses from the validators. Quantitative data were obtained from critical thinking questionnaires and student interest questionnaires. The questionnaire used is closed because there are already answer choices for each question. In the interest and critical thinking questionnaire, students have 15 valid questions, with the reliability of the questions using Cronbach's omitted formula. After being reviewed with Cronbach's negligence, it was found that the value of the student interest questionnaire was 0.67 and critical thinking was 0.64 . Questionnaire of interest and critical thinking using a Likert scale of 1-5, with positive statements Strongly Agree with a value of 5, agree with a value of 4 , moderately worth 3 , disagree with a value of 2 and strongly disagree with a value of 1. The following is a grid of interest questionnaires students and students' critical thinking skills towards the implementation of the thematic practicum guidebook Theme 2 .

Table 1. Questionnaire Grid of Students' Interests and Critical Thinking Ability

\begin{tabular}{|c|c|c|}
\hline Questionnaire & Indicator & Descriptor \\
\hline \multirow{3}{*}{$\begin{array}{l}\text { Student } \\
\text { Interest }\end{array}$} & $\begin{array}{l}\text { Fun in the Learning } \\
\text { Process }\end{array}$ & Learning process. \\
\hline & Curiosity & $\begin{array}{l}\text { Materials and media used by the teacher. } \\
\text { Teacher performance }\end{array}$ \\
\hline & $\begin{array}{l}\text { Attention } \\
\text { Involvement } \\
\text { Formulate }\end{array}$ & $\begin{array}{c}\text { Student understanding at each step of the practicum. } \\
\text { Before, during practicum and after. } \\
\text { Understand the problem or question. }\end{array}$ \\
\hline \multirow{6}{*}{$\begin{array}{l}\text { Students' } \\
\text { Critical } \\
\text { Thinking } \\
\text { Ability }\end{array}$} & Study & $\begin{array}{l}\text { Examines the relationships between given statements, } \\
\text { questions, and concepts. }\end{array}$ \\
\hline & Evaluate & Using the right strategy in solving problems and questions. \\
\hline & Conclusion & Make conclusions. \\
\hline & Formulate & Understand the problem or question. \\
\hline & Study & $\begin{array}{c}\text { Examines the relationships between given statements, } \\
\text { questions, and concepts. }\end{array}$ \\
\hline & Evaluate & Using the right strategy in solving problems and questions. \\
\hline
\end{tabular}

After the data is collected, the following data will be analyzed. The data analysis used is descriptive statistics and inferential statistics. The descriptive statistics used are the maximum value, minimum value, mean, median. Descriptive statistics were used to analyze data from the two existing questionnaires. Inferential statistical analysis to test the hypothesis that researchers use is a regression test. A regression test is a test on data to know the effect of one variable on other variables.

\section{RESULT AND DISCUSSION}

\section{Result}

The definition stage is the first stage that the author does in the research and development process of the 4-D model. This stage consists of several analyzes. The purpose of the analysis is to determine the primary direction needed to develop a practicum manual. The definition stage consists of several analyzes, namely, analysis of student characteristics and analysis of concepts. Analysis of student characteristics is the stage of analyzing the characteristics that exist in elementary school students. The age of fourth-grade 
elementary school students is usually 9-10 years. Elementary school-age children have different characteristics. According to Piaget, children aged 7-11 years are in the concrete operational stage. At the concrete operational stage, students need something concrete in learning. At this age, students also prefer interesting, challenging, and problem-solving activities. In addition, students at this age have high curiosity, like to do things directly, like to play, and are active.

Concept analysis is carried out in determining the material in the book to be developed. This analysis is based on the Basic Competencies (KD) that must be achieved in the 2013 curriculum. The KD is based on the Regulation of the Minister of Education and Culture of the Republic of Indonesia Number 24 of 2016 concerning Core Competencies and Basic Competencies of Learning. The essential competencies in class IV are comparing the life cycles of several types of living things and relating them to their conservation efforts, identifying the types of forces, including muscle force, electric force, magnetic force, gravitational force, and frictional force, linking force to the motion of objects with events in the environment, identify various energy sources, changes in energy forms, and alternative energy sources (wind, water, solar, geothermal, organic fuels, and nuclear) in everyday life, and apply the properties of light and their relationship to a sense of sight. Based on the KD analysis, there is five KD semester II grade IV SD that practicum activities must carry out. So the researchers took the basic competence of identifying various energy sources, their changes, and alternative energy sources to develop a practical manual. KD is used as a reference in the development of practical manuals. Phase Design (Planning) Formulation of objectives is based on essential competencies or concept analysis. To facilitate the formulation of learning objectives, learning indicators are determined. The next stage is the design stage. At this stage, the author selects the media and makes the initial design of the media. Here is the initial design of the Theme 2 thematic practicum book:
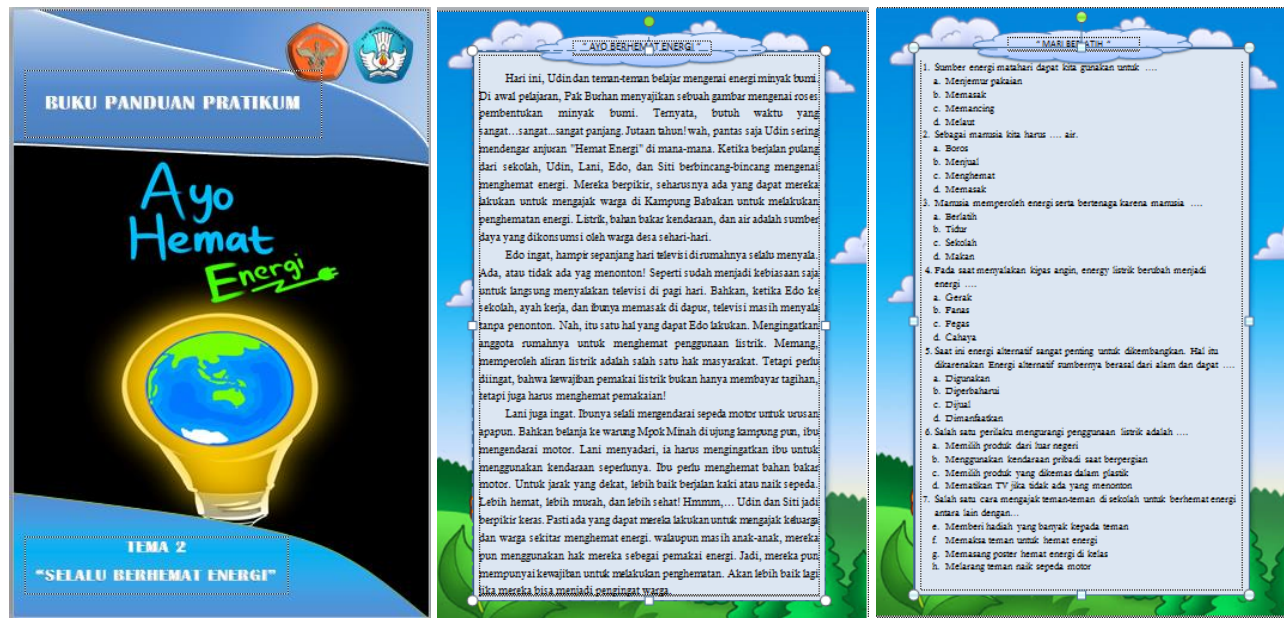

Figure 2. Cover, Reading Story, Multiple Choice Questions

The selection of the book format refers to the Regulation of the Minister of Education and Culture Number 8 of 2016 concerning Books Used by Education Units. The formats used are Page Titles, Publishing Pages, Preface, Table of Contents, List of Figures, List of Tables, Instructions for the use of Books, Contents of Books, Bibliography, Index, and Author Profile. The following is the structure of the practicum guidelines, namely the practical title, practicum objectives, theoretical basis, tools and materials, practical procedures, observation data, data analysis, and discussion and conclusions. The third stage is the development stage. The practicum book's stage was validated, namely material validation, media validation, evaluation, and teacher validation, followed by product revision. The validation assessment determines the book can be used or not. The validator gave the suggestions became a benchmark in making revisions. The revision aims to improve the product being developed. Material validation reveals that the material in the developed practicum manual needs to be completed. At the same time, the media validation revealed the need for improvement in the color of the book display. The validators stated that the practicum book had been declared valid, then the product was tested. Product trials were conducted to obtain product practicality data. The practicality of the product is obtained from teachers and students who reveal that the practical book is easy to use.

The fourth stage is the deployment stage. After the product is developed, it is then implemented in fourth-grade students of SD Negeri 45/I Sridadi. The product developed was used as a Theme 2 thematic practicum guidebook for fourth-grade students. After completion, students are asked to fill out a 
questionnaire interested in using the thematic practicum guidebook. The results of the interest data obtained can be seen in the table below. Based on the results of data analysis, it is known that the interest of SD Negeri 45/I Sridadi students in using the Theme 2 thematic practicum guidebook shows in the excellent category. The minimum score is 57 , the maximum score is 81 , the average value is 61.7 , the median is 61.00 , and the mode is 61 . Students in the excellent category are 67 students with a percentage of $45 \%$. The category is not good as many as 25 students with a percentage of $20 \%$. Enough category as many as 45 students with a percentage of 35\%. The excellent and bad categories are 0 students with $0 \%$ of the total number of students as many as 137 students. The interest questionnaire data show that students' interest in learning by using the Theme 2 thematic practicum guidebook is in a suitable category, meaning that the practicum book can increase interest in learning.

Based on the results of data analysis, it is known that the critical thinking skills of SD Negeri 45/I Sridadi students in using the Theme 2 thematic practicum guidebook show in the excellent category. The minimum score is 52 , the maximum score is 80 , the average value is 60.75 , the median is 60.32 , and the mode is 64 . Students in the wrong category are 15 students with a percentage of $10.9 \%$. Enough category as many as 15 students with a percentage of $11 \%$. The excellent category is 100 students with a percentage of $73 \%$. Excellent category as many as seven students with a percentage of 5.1 and very bad, namely 0 students with a percentage of $0 \%$. From the number of students as many as 137 students, the students' critical thinking questionnaire data showed that the student's critical thinking skills using the Theme 2 thematic practicum manual were in a suitable category. Based on the output of the SPSS 20 application, the regression test for implementing the thematic practicum guide book theme two is presented in the table above. Then it can be seen that the significance value (Sig) is 0.012 . So the value of sig 0.012 is smaller than the probability of 0.05 , or it can be written as $0.012<0.05$. So it can be concluded that students' critical thinking skills affect students' interest with the implementation of the theme two thematic practicum guidebooks for students.

\section{Discussion}

In theme two, thematic learning in class IV, the primary material is science or science learning. Science learning is related to real-life and possible solutions (Anif et al., 2020; Setiawan et al., 2017). In science learning, students can be introduced to the world of science in everyday life, read books, use digital media to obtain information related to science and conduct observational studies on nature (Hairida, 2016; Jampel et al., 2018; Lo et al., 2021). Science learning is learning that teaches about products, processes, and scientific attitudes. These three things cannot be achieved only by theoretical explanation and memorization. Science learning in elementary schools memorizes science material and an investigation of simple practicum (Chandra et al., 2020; Hairida, 2016; Suryawati \& Osman, 2018). That is, in science learning, which includes products, processes, and scientific attitudes, practicum in science learning is needed. In the practical implementation, a practical guide is needed. The practicum guide contains practical instructions as a guide for preparation, implementation, and reporting of practicum.

Practical guidelines are not specifically available in primary schools. In fact, with practicum guidelines, the practicum-based learning process will be more effective (Manikowati \& Iskandar, 2018; Novita, 2020).. The practical guidelines used are taken from student books and worksheets. The material taught will be easier to remember and live by practicing science process skills (Misbah et al., 2018; Ningsi et al., 2021). With the thematic practicum guidebook Theme 2 , the implementation of the practicum can be more focused, planned, and systematic. The activity of analyzing student characteristics is a method used to understand students' interests and needs (Angraini, 2017; Tafqihan, 2011). After that, a concept analysis was carried out. Concept analysis is carried out to determine the material that will be practiced and published in the practicum manual (Hamdunah et al., 2016; Setiyani, Putri et al., 2020). Next, the formulation of learning objectives. Learning objectives are competency targets to be achieved from the learning process. At the design stage, the book format is selected, and an initial book design is made. After selecting the book format, then the initial media or book design is created. The initial design of the book becomes a reference in developing the book. The use of the thematic practicum book that has been developed has a good effect on increasing student interest in learning which can be seen from the results of the student assessment table on learning interest. Interest is a mental tendency towards something consisting of feelings of pleasure, attention, sincerity, and a motive in achieving a goal (Fadillah, 2016; Lestari, 2015). So that the level of attention or pleasure of students towards the subject is influenced by the level of interest of the student (Khoiruddin et al., 2016; Sari, 2019). students who have an interest in learning activities will try harder when compared to students who are less interested in learning (Laa et al., 2017; Yunitasari \& Hanifah, 2020). Previous research stated that the better the student's interest in learning, the better the student's learning outcomes (Maison et al., 2019). So that the use of the Theme 2 thematic practicum guidebook affects student interest. 
The student's critical thinking ability using the thematic practicum book that has been developed has a good effect on critical thinking skills. It can be seen from the student's critical thinking questionnaire table. Critical thinking ability is the ability to review or evaluate information (Sapeni \& Said, 2020; Saprudin et al., 2019). These stages of critical thinking skills are apparent in the practicum-based learning process (Al-Idrus et al., 2021). The practicum-based learning process will help students train and develop critical thinking skills (Ari Astuti et al., 2019; Mayub et al., 2020). In the practicum process, students will train students' concentration and focus on learning (Rante et al., 2013). So that students' critical thinking skills are needed in the practical learning process. By using the Theme 2 thematic practicum manual, students will focus on practical activities. The guidebook provides an understanding of each step of the practicum activity and explains the material. So that students' critical thinking skills are trained and developed by using the Theme 2 thematic practicum guidebook in the learning process.

The position of this research is with previous research that applies science-based education so that students can gain scientific skills, while in this study, the use of practical thematic guidebooks in elementary schools is in Theme 2 (Can et al., 2017). Research that has been carried out by applying guidebooks as flexible learning has a position with this research, where the guidebooks used aim to increase student interest in learning science in elementary schools (Kimianti \& Prasetyo, 2019; Novita, 2020). In other studies, the ability to think critically increases with the use of a medium, namely comic books (Yonanda et al., 2019). The implication of this research is to develop a thematic practicum guidebook Theme 2 . Also, the book that has been developed can be a learning guide in the practicum process. In addition, the Theme 2 thematic practicum guidebook is a teaching material that is by the needs of students and can be used as a source of independent learning. The development of this guidebook aims to increase students' interest in science-based learning. Because in general, for students, learning is difficult to understand, so students are lazy and less enthusiastic in the science learning process. So that by doing practicum, it is expected that students can easily understand the lesson. Using the thematic practicum guide book theme two can also develop students' critical thinking skills. The novelty in this research is the development of a Theme 2 thematic practicum manual for elementary school students in grade IV. Moreover, the use of this guidebook has been proven to increase students' interest in the science learning process. Meanwhile, the limitations in this study are only in Theme 2 for grade IV SD, which the researchers developed, namely the thematic practicum guidebook Theme 2 .

\section{CONCLUSION}

Implementing the Theme 2 thematic practicum guidebook in the learning process affects students' interests and critical thinking skills. The thematic learning process in the current learning process with the main content of science or science requires a practicum-based learning process. Practical activities provide hands-on and meaningful experiences. The existence of practical activities can prove the theories students have studied to arouse students' interest in learning. Students' critical thinking skills are well-formed because they are influenced by media that encourages students to think critically. Therefore, teachers need to hold practical activities in learning activities so that students are helped in forming students' critical thinking skills.

\section{REFERENCES}

Al-Idrus, S. W., Muti'ah, M., \& Rahmawati, R. (2021). Pengembangan Kemampuan Berpikir Kreatif Mahasiswa melalui Pembelajaran Berbasis Proyek pada Mata Kuliah Kimia Lingkungan di Masa Pandemic Covid 19. AS-SABIQUN, 3(1), 14-25. https://doi.org/10.36088/ASSABIQUN.V3I1.1117.

Alnajdi, S. M. (2018). The Effectiveness of Designing and Using a Practical Interactive Lesson based on ADDIE Model to Enhance Students' Learning Performances in University of Tabuk. Journal of Education and Learning, 7(6), 212. https://doi.org/10.5539/jel.v7n6p212.

Andayani, S. (2017). Implementasi Model Pembelajaran Reciprocal Teaching Untuk Meningkatkan Kemampuan Berpikir Kritis Dan Hasil Belajar. Aksioma, 5(2). https://doi.org/10.24127/ajpm.v5i2.675.

Angraini, R. (2017). Karakteristik Media Yang Tepat Dalam Pembelajaran Pendidikan Kewarganegaraan (Pkn) Sebagai Pendidikan Nilai. Journal of Moral and Civic Education, 1(1), 14-24. https: //doi.org/10.24036/8851412020171116.

Anif, S., Sutopo, A., \& Prayitno, H. J. (2020). Lesson study validation: Model for social and natural sciences teacher development in the implementation of national curriculum in Muhammadiyah schools, Indonesia. Universal Journal of Educational Research, 8(1), 253-259. https: //doi.org/10.13189/ujer.2020.080132. 
Ardiani, N. F. W., Guna, N. A., \& Novitasari, R. (2013). Pembelajaran Tematik Dan Bermakna Dalam Perspektif $\begin{array}{lllll}\text { Revisi Taksonomi } \quad \text { Bloom. } & \text { Satya } & \text { 93 }\end{array}$ https: //doi.org/10.24246/j.sw.2013.v29.i2.p93-107.

Ari Astuti, E., Wardani, S., \& Kadarwati, S. (2019). The effectiveness of practicum-based worksheet based on salt hydrolysis material viewed from the aspect of laboratory skills and interpersonal intelligence learners. Journal of Education and Learning (EduLearn), 13(4), 502-509. https: //doi.org/10.11591/edulearn.v13i4.12397.

Arico, F., Gillespie, H., Lancaster, S., Ward, N., \& Ylonen, A. (2018). Lessons in learning gain: Insights from a pilot project. Higher Education Pedagogies, 3(1), 249-265. https: //doi.org/10.1080/23752696.2018.1454845.

Arsy, H. I., Prasetyo, A. P. B., \& Subali, B. (2020). Predict-Observe-Explain Strategy with Group Investigation Effect on Students ' Critical Thinking Skills and Learning Achievement. Journal of Primary Education, 9(1), 75-83. https://doi.org/10.15294/jpe.v9i1.29109.

Asrial, A., Syahrial, S., Maison, M., Kurniawan, D. A., \& Perdana, R. (2020). A study of Traditional Games "Engklek" in Mathematics for Elementary School. Jurnal Ilmu Pendidikan, 26(1), 15-21. https: //doi.org/10.17977/UM048V26I1P15-21.

Asrial, Syahrial, Maison, Kurniawan, D. A., \& Piyana, S. O. (2020). Ethnoconstructivism E-Module to Improve Perception, Interest, and Motivation of Students in Class V Elementary School. JPI Ournal Pendidikan Indonesia), 9(1), 30-41. https://doi.org/10.23887/jpi-undiksha.v9i1.19222.

Awe, E. Y., \& Benge, K. (2017). Hubungan Antara Minat Dan Motivasi Belajar Dengan Hasil Belajar Ipa Pada Siswa Sd. Journal of Education Technology, 1(4), 231. https://doi.org/10.23887/jet.v1i4.12859.

Bettencourt, C., Velho, J. L., \& Almeida, P. A. (2011). Biology teachers' perceptions about Science-TechnologySociety (STS) education. Procedia - Social and Behavioral Sciences, 15. https://doi.org/10.1016/j.sbspro.2011.04.262.

Can, B., Yıldız-Demirtaş, V., \& Altun, E. (2017). The effect of project-based science education programme on scientific process skills and conceptions of kindergarten students. Journal of Baltic Science Education. https://doi.org/10.33225/jbse/17.16.395.

Candra, I., Sulistya, N., \& Prasetyo, T. (2018). Pengembangan Instrumen Sikap Sosial Tematik Siswa SD Kelas IV. Jurnal Ilmiah Sekolah Dasar, 2(4), 455. https://doi.org/10.23887/jisd.v2i4.16167.

Chandra, A. Y., Kurniawan, D., \& Musa, R. (2020). Perancangan Chatbot Menggunakan Dialogflow Natural Language Processing (Studi Kasus: Sistem Pemesanan pada Coffee Shop). Jurnal Media Informatika Budidarma, 4(1), 208. https://doi.org/10.30865/mib.v4i1.1505.

Draijer, J. M., Draijer, J., Bakker, A., Slot, E., \& Akkerman, S. (2020). The Multidimensional Structure of Interest. Frontline Learning Research, 8(4), 18-36. https://doi.org/10.14786/flr.v8i4.577.

Fadillah, A. (2016). Analisis Minat Belajar Dan Bakat Terhadap Hasil Belajar Matematika Siswa. $M$ A T H L I $N$ E: Jurnal Matematika Dan Pendidikan Matematika, 1(2), 113-122. https://doi.org/10.31943/mathline.v1i2.23.

Faisal, \& Martin, S. N. (2019). Science education in Indonesia: past, present, and future. Asia-Pacific Science Education, 5(1). https://doi.org/10.1186/s41029-019-0032-0.

Fauziah, A., Rosnaningsih, A., \& Azhar, S. (2017). Hubungan Antara Motivasi Belajar Dengan Minat Belajar Siswa Kelas IV SDN Poris Gaga 05 Kota Tangerang. JURNAL JPSD, Vol. 4 No, 47-53. https://doi.org/10.26555/jpsd.v4i1.a9594.

Fitriani*, W., Suwarjo, S., \& Wangid, M. N. (2021). Berpikir Kritis dan Komputasi: Analisis Kebutuhan Media Pembelajaran di Sekolah Dasar. Jurnal Pendidikan Sains Indonesia, 9(2), 234-242. https: //doi.org/10.24815/jpsi.v9i2.19040.

Gavrilenko, N. (2018). Online model for teaching and learning the specialized translation. Eurasia Journal of Mathematics, Science and Technology Education, 14(6), 2711-2717. https://doi.org/10.29333/ejmste/85421.

Gürsoy, G. (2021). Digital storytelling: Developing 21st century skills in science education. European Journal of Educational Research, 10(1), 97-113. https://doi.org/10.12973/EU-JER.10.1.97.

Hadiyanti, N. F. D., Hobri, Prihandoko, A. C., Susanto, Murtikusuma, R. P., Khasanah, N., \& Maharani, P. (2021). Development of mathematics e-module with STEM-collaborative project based learning to improve mathematical literacy ability of vocational high school students. Journal of Physics: Conference Series, 1839(1). https://doi.org/10.1088/1742-6596/1839/1/012031.

Hairida, H. (2016). The effectiveness using inquiry based natural science module with authentic assessment to improve the critical thinking and inquiry skills of junior high school students. Jurnal Pendidikan IPA Indonesia, 5(2), 209-215. https://doi.org/10.15294/jpii.v5i2.7681.

Hamdunah, Yunita, A., Zulkardi, \& Muhafzan. (2016). Development a Constructivist Module and Web on Circle and Sphere Material with Wingeom Software. Journal on Mathematics Education, 7(2), 109- 
116. https://doi.org/10.22342/jme.7.2.3536.109-116.

Hartini, S., Misbah, Dewantara, D., Oktovian, R. A., \& Aisyah, N. (2017). Developing learning media using online prezi into materials about optical equipments. Jurnal Pendidikan IPA Indonesia, 6(2), 313317. https://doi.org/10.15294/jpii.v6i2.10102.

Hwang, G. J., Wu, P. H., \& Chen, C. C. (2012). An online game approach for improving students' learning performance in web-based problem-solving activities. Computers and Education, 59(4), 12461256. https://doi.org/10.1016/j.compedu.2012.05.009.

Jampel, I. N., Fahrurrozi, Artawan, G., Widiana, I. W., Parmiti, D. P., \& Hellman, J. (2018). Studying natural science in elementary school using nos-oriented cooperative learning model with the NHT type. Jurnal Pendidikan IPA Indonesia, 7(2), 138-146. https://doi.org/10.15294/jpii.v7i2.9863.

Khoiruddin, M. A., Taulabi, I., \& Imron, A. (2016). Menumbuhkan Minat Baca Sejak Dini di Taman Baca Masyarakat. Journal An-Nafs: Kajian Penelitian Psikologi. https://doi.org/10.33367/psi.v1i2.295.

Kimianti, F., \& Prasetyo, Z. K. (2019). Pengembangan E-Modul Ipa Berbasis Problem Based Learning Untuk Meningkatkan Literasi Sains Siswa. Kwangsan: Jurnal Teknologi Pendidikan, 7(2), 91. https: //doi.org/10.31800/jtp.kw.v7n2.p91--103.

Krissandi, A. D. S. (2018). Pengembangan Video Tematik Sebagai Pengantar Pembelajaran Kurikulum 2013 di Sekolah Dasar. Premiere Educandum : Jurnal Pendidikan Dasar Dan Pembelajaran, 8(1), 68-77. https://doi.org/10.25273/pe.v8i1.2233.

Kurniawan, W., Darmaji, D., Astalini, A., Kurniawan, D. A., \& Hidayat, M. (2019). Multimedia physics practicum reflective material based on problem solving for science process skills. International Journal of Evaluation and Research in Education (IJERE), 8(4), 590-595. https://doi.org/10.11591/ijere.v8i4.20258.

Laa, N., Winata, H., \& Meilani, R. I. (2017). Pengaruh Model Pembelajaran Kooperatif Tipe Student Teams Achievement Division Terhadap Minat Belajar Siswa. Jurnal Pendidikan Manajemen Perkantoran, 2(2), 139. https://doi.org/10.17509/jpm.v2i2.8115.

Lee, S., \& Kim, S. H. (2018). Scientific Knowledge and Attitudes Toward Science in South Korea: Does Knowledge Lead to Favorable Attitudes? Science Communication, 40(2), 147-172. https: //doi.org/10.1177/1075547017753189.

Lestari, I. (2015). Pengaruh Waktu Belajar dan Minat Belajar terhadap Hasil Belajar Matematika. Formatif: Jurnal Ilmiah Pendidikan MIPA, 3(2), 115-125. https://doi.org/10.30998/formatif.v3i2.118.

Lo, J.-H., Lai, Y.-F., \& Hsu, T.-L. (2021). The Study of AR-Based Learning for Natural Science Inquiry Activities in Taiwan's Elementary School from the Perspective of Sustainable Development. Sustainability, 13(3). https://doi.org/10.3390/su13116283.

Ma'ratusholihah, Priyanto, \& Damayani, A. . (2019). Pengembangan media pembelajaran tematik ular tangga berbagai pekerjaan. Mimbar PGSD Undiksha, $7(3)$. https: //doi.org/10.23887/jjpgsd.v7i3.19411.

Maison, Agus Kurniawan, D., Perdana, R., \& Anggraini, L. (2019). The Phenomenon of Physicology Senior High School Education: Relationship of Students' Attitudes toward Physic, Learning Style, Motivation. Universal Journal of Educational Research, 7(10), 2199-2207. https: //doi.org/10.13189/ujer.2019.071018.

Manikowati, Nf., \& Iskandar, D. (2018). Pengembangan Model Mobile Virtual Laboratorium Untuk Pembelajaran Praktikum Siswa Sma. Jurnal Kwangsan, 6(1), 23. https://doi.org/10.31800/jtp.kw.v6n1.p23--42.

Mayub, A., Suryani, E., \& Farid, M. (2020). Implementation of discovery learning model based on calor characteristic bricks mixed by (Durio zibethinus) and coconut (cocos nucifera) skin to improve students' cognitive learning outcomes. Jurnal Pendidikan IPA Indonesia, 9(2), 287-293. https://doi.org/10.15294/jpii.v9i2.23803.

McCormick, N. J., Clark, L. M., \& Raines, J. M. (2015). Engaging Students in Critical Thinking and Problem Solving: A Brief Review of the Literature. Journal of Studies in Education, 5(2), 100-113. https://doi.org/10.5296/jse.v5i4.8249.

Misbah, M., Wati, M., Rif'at, M. F., \& prastika, miranti diah. (2018). Pengembangan Petunjuk Praktikum Fisika Dasar I Berbasis 5M Untuk Melatih Keterampilan Proses Sains dan Karakter Wasaka. Jurnal Fisika Flux: Jurnal Ilmiah Fisika FMIPA Universitas Lambung Mangkurat, 15(1), 26-30. https: //doi.org/10.20527/flux.v15i1.4480.

Mulyati, T., Kusumadewi, R. F., \& Ulia, N. (2021). Pembelajaran Interaktif Melalui Media Komik Sebagai Solusi Pembelajaran Dimasa Pandemi. Pedagogi: Jurnal Penelitian Pendidikan, 8(1). https://doi.org/10.25134/PEDAG0GI.V8I1.4054.

Muskania, R. T., Badariah, S., \& Mansur, M. (2019). Pembelajaran Tematik Menggunakan Media Video Scribe Pada Siswa Kelas IV Sekolah Dasar. Elementary: Islamic Teacher Journal, 7(1). 
https://doi.org/10.21043/elementary.v7i1.4927.

Mutakinati, \& Anwari. (2018). Analysis Of Students ' Critical Thinking Skill Of Middle School Through Stem Education Project-Based Learning. Jurnal Pendidikan IPA Indonesia, 7(1), 54-65. https://doi.org/10.15294/jpii.v7i1.10495.

Muzijah, R., Wati, M., \& Mahtari, S. (2020). Pengembangan E-modul Menggunakan Aplikasi Exe-Learning untuk Melatih Literasi Sains. Jurnal Ilmiah Pendidikan Fisika, 4(2), 89. https://doi.org/10.20527/jipf.v4i2.2056.

Ningsi, A. P., Purwaningsih, S., \& Darmaji, D. (2021). Pengembangan penuntun Praktikum Ekektronik Berbasis Keterampilan Proses Sains Materi Suhu dan Kalor untuk SMP/MTs. Edumaspul: Jurnal Pendidikan, 5(1), 242-251. https://doi.org/10.33487/EDUMASPUL.V5I1.1159.

Novita, E. (2020). Pengembangan Buku Pedoman Praktikum Berbasis Keterampilan Proses Dasar Sains Kelas IV Sekolah Dasar. Journal Evaluation in Education (JEE), 1(1), 34-41. https://doi.org/10.37251/JEE.V1I1.38.

Nugraha, A. J., Suyitno, H., \& Susilaningsih, E. (2017). Analisis Kemampuan Berpikir Kritis Ditinjau dari Keterampilan Proses Sains dan Motivasi Belajar melalui Model PBL. Journal of Primary Education. https://doi.org/10.15294/jpe.v6i1.14511.

Nugroho, A., Ilmiani, D., \& Rekha, A. (2021). EFL Teachers' Challenges and Insights of Online Teaching amidst Global Pandemic. Metathesis: Journal of English Language, Literature, and Teaching, 4(3), 277. https://doi.org/10.31002/metathesis.v4i3.3195.

Nugroho, P. B., Nusantara, T., As'ari, A. R., Sisworo, Hidayanto, E., \& Susiswo. (2018). Critical Thinking Disposition: Students Skeptic in Dealing with Ill-Logical Mathematics Problem. International Journal of Instruction, 11(3), 635-648. https://doi.org/10.12973/iji.2018.11343a.

Nurmanita, N., Siagian, P., \& Sitompul, P. (2019). Development of Learning Device through Problem Based Learning Model Assisted by Geogebra to Improve Students' Critical Mathematical Thinking Ability. Journal of Mathematical Sciences and Applications, 7(1), 1-9. https://doi.org/10.12691/JMSA-7-11.

Purnami, W., Ashadi, Suranto, Sarwanto, Sumintono, B., \& Wahyu, Y. (2021). Investigation of Person Ability and Item Fit Instruments of Eco Critical Thinking Skills in Basic Science Concept Materials for Elementary Pre-Service Teachers. Jurnal Pendidikan IPA, 10(1), 127-137. https://doi.org/10.15294/jpii.v10i1.25239.

Rante, P., Sudarto, \& Ihsan, N. (2013). Pengembangan multimedia pembelajaran fisika berbasis audio-video eksperimen listrik dinamis di smp. Jurnal Pendidikan IPA Indonesia, 2(2), 203-208. https://doi.org/10.15294/jpii.v2i2.2724.

Riani, R. P., Huda, K., \& Fajriyah, K. (2019). Pengembangan Media Pembelajaran Tematik "Fun Thinkers Book" Tema Berbagai Pekerjaan. Jurnal Sinektik, 2(2), 173. https://doi.org/10.33061/js.v2i2.3330.

Riwanti, R., \& Hidayati, A. (2019). Pengembangan Modul Pembelajaran Tematik Berbasis Pendidikan Karakter Di Kelas V Sekolah Dasar. Jurnal Basicedu, 3(2), 572-581. https://doi.org/10.31004/basicedu.v3i2.41.

Rosala, D., \& Budiman, A. (2020). Local Wisdom-based Dance Learning: Teaching Characters to Children through Movements. Mimbar Sekolah Dasar, 7(3), 304-326. https://doi.org/10.17509/mimbarsd.v7i3.28185.

Rubini, B., Permanasari, A., \& Yuningsih, W. (2018). Learning Multimedia Based on Science Literacy on the Lightning Theme. Journal of Science Learning and Research, 4(2), 89-104. https://doi.org/10.30870/jppi.v4i2.3926.

Sakliressy, M. T., Sunarno, W., \& Nurosyid, F. (2021). Students Scientific Attitude in Learning Physics Using Problem Based Learning Model with Experimental and Project Methods. Jurnal Ilmiah Pendidikan Fisika Al-Biruni. https://doi.org/10.24042/jipfalbiruni.v10i1.8347.

Samri, F., Rewo, J. M., \& Laksana, D. N. . (2020). Electronic Thematic Teaching Multimedia with Local Culture Based Materials and Its Effect on Conceptual Mastery of Primary School Students. European Journal of Education Studies, 7(2), 625-641. https://doi.org/10.46827/ejes.v7i12.3474.

Samsudin, Achmad, Bias Cahyani, P., Rusdiana, D., Aminudin, A. H., Coştu, B., Samsudin, A., Cahyani, P. B., Rusdiana, D., \& Coştu, A. A. H. (2021). Development of a multitier open-ended work and energy instrument (MOWEI) using Rasch analysis to identify students' misconceptions. Cypriot Journal of Educational Sciences, 16(1), 16. https://doi.org/10.18844/cjes.v16i1.5504.

Samsudin, Asep, Kelana, J. B., \& Muftianti, A. (2019). Utilization of Internet-Based Learning Media in Enhancing Science Literacy Capabilities of Pgsd Students. PrimaryEdu - Journal of Primary Education, 3(2), 91. https://doi.org/10.22460/pej.v3i2.1284.

Sapeni, M. A.-A. R., \& Said, S. (2020). The effectiveness of case-based learning in increasing critical thinking of nursing students: A literature review. Enfermería Clínica, 30(2). 
https://doi.org/10.1016/j.enfcli.2019.07.073.

Saprudin, S., Liliasari, S., Prihatmanto, A. S., \& Setiawan, A. (2019). Pre-service physics teachers' thinking styles and its relationship with critical thinking skills on learning interference and diffraction. Journal of Physics: Conference Series, 1157(3), 1-6. https://doi.org/10.1088/1742$6596 / 1157 / 3 / 032029$.

Sari, P. A. P. (2019). Hubungan Literasi Baca Tulis Dan Minat Membaca Dengan Hasil Belajar Bahasa Indonesia. Journal for Lesson and Learning Studies, 3(1). https://doi.org/10.23887/jlls.v3i1.24324.

Seruni, R., Munawaroh, S., Kurniadewi, F., \& Nurjayadi, M. (2020). Implementation of e-module flip PDF professional to improve students' critical thinking skills through problem based learning. Journal of Physics: Conference Series, 1521(4), 1-6. https://doi.org/10.1088/1742-6596/1521/4/042085.

Setiawan, A. R. (2020). Desain Pembelajaran Tematik untuk Membimbing Siswa Sekolah Dasar dalam Memperoleh Literasi Saintifik. Journal of Petrology, 369(1), 1689-1699. https: //doi.org/10.1017/CB09781107415324.004.

Setiawan, Innatesari, D. K., Sabtiawan, W. B., \& Sudarmin, S. (2017). The development of local wisdom-based natural science module to improve science literation of students. Jurnal Pendidikan IPA Indonesia, 6(1), 49-54. https://doi.org/10.15294/jpii.v6i1.9595.

Setiyani, Putri, D. P., Ferdianto, F., \& Fauji, S. H. (2020). Designing a Digital Teaching Module Based on Mathematical Communication in Relation and Function. Journal on Mathematics Education, 11(2), 226-236. https://doi.org/10.22342/jme.11.2.7320.223-236.

Silva, A. B. Da, Bispo, A. C. K. de A., Rodriguez, D. G., \& Vasquez, F. I. F. (2018). Problem-based learning: A proposal for structuring PBL and its implications for learning among students in an undergraduate management degree program. REGE Revista de Gestão, 25(2), 160-177. https://doi.org/10.1108/REGE-03-2018-030.

Suarsana, I. M., Mahayukti, G. A., Sudarma, K., \& Yoga, N. B. A. (2018). Development of Interactive Mathematics Learning Media on Statistics Topic for Hearing-impaired Student I Made Suarsana a. International Research Journal of Engineering, IT \& Scientific Research, 4(6), 55-66. https://doi.org/10.21744/irjeis.v4n6.377.

Sugiyanto, S., Wena, M., \& Isnandar, I. (2019). Developing Learning Materials Based On Training Within Industry (Twi) To Improve The Building Construction Student's Learning Outcomes. Jurnal Ilmu Pendidikan, 24(2). https://doi.org/10.17977/um048v24i2p80-85.

Sunarti, Rahmawati, S., \& Wardani, S. (2016). Pengembangan Game Petualangan "Si Bolang” sebagai Media Pembelajaran Tematik untuk Meningkatkan Motivasi dan Prestasi Belajar Siswa Kelas V Sekolah Dasar. Jurnal Cakrawala Pendidikan, 5(1), 58-68. https://doi.org/10.21831/cp.v1i1.8365.

Suryawati, E., \& Osman, K. (2018). Contextual learning: Innovative approach towards the development of students' scientific attitude and natural science performance. Eurasia Journal of Mathematics, Science and Technology Education, 14(1), 61-76. https://doi.org/10.12973/ejmste/79329.

Suyono, Harsiati, \& Wulandari. (2017). Implementasi Gerakan Literasi Sekolah pada Pembelajaran Tematik di Sekolah Dasar Sekolah Dasar: Kajian Teori dan Praktik Pendidikan. Jurnal Sekolah Dasar Kajian Teori Dan Praktik Pendidikan, 26(2), 116-123. https://doi.org/10.17977/um009v26i22017p116.

Syafrijal, \& Desyandri. (2019). Deveopment Of Integrated Thematic Teaching Materials With Project Based Learning Models In Class IV of Primary School. International Journal of Educational Dynamics/IJEDS, 1(2), 87-92. https://doi.org/10.24036/ijeds.v1i2.110.

Tafqihan, Z. (2011). Karakteristik Dan Pemilihan Media Pembelajaran Dalam E-Learning. Cendekia: Jurnal Kependidikan Dan Kemasyarakatan, 9(2), 141-154. https://doi.org/10.21154/cendekia.v9i2.871.

Tanti, T., Kurniawan, D. A., \& Pratiwi, N. I. S. (2019). Identifikasi Sikap Peserta Didik terhadap Mata Pelajaran Fisika di Sekolah Menengah Atas Negeri 5 Kota Jambi. UPEJ Unnes Physics Education Journal, 8(1), 34-43. https://doi.org/10.15294/UPEJ.V8I1.29510.

Tanti, T., Kurniawan, D. A., Wirman, R. P., Fitriani, R. S., Pratiwi, N. I. S., \& Yuhanis, E. (2020). Relationship Attitude Natural Sciences To Responsibility In Junior High School. Jurnal Pendidikan Sains Indonesia, 8(2), 306-318. https://doi.org/10.24815/JPSI.V8I2.17117.

Turan, M. B., \& Koç, K. (2018). The impact of self-directed learning readiness on critical thinking and selfefficacy among the students of the school of physical education and sports. International Journal of Higher Education, 7(6), 98-105. https://doi.org/10.5430/ijhe.v7n6p98.

Wahyuningsih, E. T., Purwanto, A., \& Medriati, R. (2021). Hubungan Minat Belajar Dengan Hasil Belajar Fisika Melalui Model Project Based Learning Di Kelas XI MIPA SMAN 6 Kota Bengkulu. Jurnal Kumparan Fisika, 4(2), 77-84. https://doi.org/10.33369/JKF.4.2.77-84.

Wang, P.-H., Wu, P.-L., Yu, K.-W., \& Lin, Y.-X. (2015). Influence of Implementing Inquiry-based Instruction on Science Learning Motivation and Interest: A Perspective of Comparison. Procedia - Social and Behavioral Sciences, 174,1292-1299. https: //doi.org/10.1016/j.sbspro.2015.01.750. 
Wright, J. S., Read, D., Hughes, O., \& Hyde, J. (2018). Tracking and assessing practical chemistry skills development: practical skills portfolios. New Directions in the Teaching of Physical Sciences, 13(1). https://doi.org/10.29311/ndtps.v0i13.2905.

Yaldiz, N., \& Bailey, M. (2019). The Effect of Critical Thinking on Making the Right Decisions in the New Venture Process. Procedia Computer Science, 158, 281-286. https://doi.org/10.1016/j.procs.2019.09.053.

Yonanda, D. A., Yuliati, ; A, \& Saputra, Y. S. (2019). Development Problem-Based Comic Book as Learning Media for Improving Students' Critical Thinking Ability in Primary School. Mimbar Sekolah Dasar, 6(3), 341-348. https://doi.org/10.17509/mimbar-sd.v6i3.22892.

Yuniarti, A., \& Radia, E. H. (2020). Development of Comic Mathematics Teaching Materials on Flat- Building Material to Increase Reading Interest in Class IV Elementary School Students. Journal of Education Technology, 4, 415-423. https://doi.org/10.23887/jet.v4i4.30034.

Yunitasari, R., \& Hanifah, U. (2020). Pengaruh Pembelajaran Daring terhadap Minat Belajar Siswa pada Masa COVID 19. Edukatif: Jurnal Ilmu Pendidikan, 2(3), 232-243. https://doi.org/10.31004/edukatif.v2i3.142. 